\title{
Information Professionals 2050: Educating the next generation of information professionals ${ }^{1}$
}

\author{
Barbara B. Moran* and Gary Marchionini \\ University of North Carolina, Chapel Hill, NC, USA
}

Over the past decade in the United States an enormous amount of critical attention has been focused upon all aspects of higher education. Much of this attention has been spawned by utilitarian concerns about economic costs and subsequent career return on investment, ${ }^{2}$ and by innovations in technology that lead to globalization and alternative modes of teaching and learning. Scientific and technical advances have become increasingly dependent on interdisciplinary teams that leverage diversity of thinking and work practices to solve complex problems and develop new fields of study that aggregate or subsume traditional boundaries. The structure and traditions of higher education resist development of interdisciplinary instructional degrees and programs.

Critics of education have been especially harsh in judging those schools designed to educate individuals to enter various types of professions. Professional education has always faced tension in balancing theory and practice and today's utilitarian concerns tend to emphasize translating theory to practice and embracing technology to improve productivity. These professional schools have been reproached for providing education that is outdated and inappropriate to meet the needs of the modern age. Professional schools of all types are now reconsidering long accepted pedagogical approaches and searching for ways to modernize both what is taught and how it is taught. Many large scale assessments of professional education in specific professions have attempted to provide new alternative approaches. For instance, the Carnegie Foundation for the Advancement of Teaching has recently funded a series of studies examining the educational preparation for many professions, including medicine, nursing, engineering, law and the clergy $[1,4,5,8,9]$.

The changes that are occurring within the environment in which professional schools operate necessitate a reexamination of the old patterns of education. These traditional models have become outdated in the modern world where the nature of higher education, libraries, and information resources are affected by globalization, new technologies, multiculturalism and both financial and environmental constraints. As part of this reexamination, it is time for the institutions which prepare information professionals to re-envision the education that will be needed for the next half-century. Information Professionals 2050

\footnotetext{
${ }^{1}$ This work is licensed under the Creative Commons Attribution-Noncommercial No Derivations Works 3.0 Unported license. You are free to Share this work (copy, Distribute and transmit) under the following conditions: attribution, noncommercial and no derivative works. To view a copy of this license, visit http://creativecommons.org/licenses/by-nc-sa/3.0/.

${ }^{*}$ Corresponding author. E-mail: bmoran@email.unc.edu.

${ }^{2}$ The much-trumpeted report that student loan debt in the US now exceeds all US credit card debt has honed awareness that education is a consumer resource as much as it is a creator of resources [2].
} 
is designed to bring together thought leaders in the diverse information field to create a blueprint for educating the next generation of information professionals.

The School of Information and Library Science at the University of North Carolina at Chapel Hill (SILS) has been a leader in training librarians for decades, and over the past twenty-five years we have developed our MSIS and BSIS programs to broaden our programs to serve the information management needs of business, industry and government. As one of the leading information programs, we are taking the opportunity of our 80th anniversary celebration to sponsor this symposium as a way to help the field and all information schools begin to think about the changes that will be necessary to successfully produce that next generation of information leaders.

Today most information professionals are educated in what have become known as i-Schools. Some of these schools were created specifically to address information education, some were created by merging existing departments (e.g., computer science and media studies), some are aggregations of faculty and courses from the entire gamut of academic departments, but most adapted from roots in education for librarianship. Regardless of their origins, i-Schools around the globe are evolving rapidly. We use an evolutionary change model to illustrate this evolution and to identify the challenges that all i-Schools face regardless of genesis.

The first "library" school was established at Columbia in 1883 by Melvil Dewey; however, most of the early programs to prepare librarians were located not in institutions of higher education but in libraries. In the late 19th and early 20th century when librarianship was beginning to emerge as a profession, education for librarians, like that of lawyers and many other professionals, was commonly based on an apprenticeship model. Aspiring librarians were prepared for the profession either on the job by more experienced librarians or in specialized educational programs located in large public libraries. It was not until after the Carnegie Foundation commissioned Charles C. Williamson to study training for librarianship that library education was brought into the academy. The Williamson Report of 1923 [12] made many recommendations to strengthen the education of librarians, but among the most important was that preparation for the profession should move from public libraries to universities. Subsequent to the Williamson report there have been numerous efforts (including comprehensive reviews such as the Wheeler Report (1946), the Conant Report (1980), the King Report (1986) and the KALIPER Report (2000) $[3,6,7,11]$ to survey the state of education for information professionals and make recommendations for its reform. Information Professionals 2050 is designed to provide the groundwork for another such reexamination.

In the decades since the schools originally designed to prepare librarians moved to the higher education sphere, these schools themselves have evolved to meet the needs for new types of information professions in careers that did not exist when the schools came into existence. Originally the education in these schools was narrowly focused on preparing individuals to work in one type of information agency, the library; however, for at least the last 40 years the focus has been much broader. Our schools have moved from a Ptolemaic information world with the library at the center to a dynamic, Copernican universe with information at its center and with libraries as one of the many planets revolving around this information core [10]. Now the i-Schools prepare a wide range of information professionals including information architect, data analyst, database administrator, web developer, ontologist, usability engineer, social media strategist, data curator, chief information officer and, of course, librarian, archivist and museum curator. This range makes it more difficult to foresee the preparation needed for future information specialists because students come to our school to be prepared for so many diverse careers. Compounding the difficulty is the fact that it is impossible to predict the information environment where our graduates will be working even a decade from now. Although it is a daunting challenge, the i-Schools 
of today need to rethink the education being provided so they are able to better prepare the professionals of tomorrow. Some questions i-Schools grapple with include:

- How do they recruit the best and brightest students and sustain life-long learning relationships with those students?

- How diverse a faculty should they recruit to represent the spectrum of disciplines that are critical to modern LIS schools?

- How should i-Schools deal with the task of integrating knowledge and practice in a way that will prepare their graduates for the challenges of the rapidly changing information environment of the future?

- How can these schools leverage information technologies to be more effective and efficient?

- How do they build mutually beneficial partnerships with information industries and agencies? With different schools and departments?

- How do they assess the schools? The faculty? Student outcomes?

The information professions are at an inflection point in time. The environment in which all information professionals operate has been revolutionized, primarily due to profound changes in technology. Technology has transformed almost all aspects of our world, and has certainly transformed the careers into which we send our graduates. These technological changes have altered traditional methods of information storage and retrieval that have endured for centuries. Scholarly communication has been transformed and user expectations heightened. Access to information is ubiquitous and information permeates all aspects of our lives. This is no evolutionary change but a disruptive one as we move from a world where information was contained within walls in finite containers such as books and filing cabinets to one where information is virtual and omnipresent. Information schools once prepared professionals to work in a specific type of institution; now they are preparing professionals for careers in a world where the institutions that employ them (if they actually do work within an institution) are of many types and serve many different purposes. Once information was typically dealt with on a local scale; now information professionals work with information that is international in scope, linking institutions and individuals across the globe in real time. These profound changes in the information world demand equally profound changes in the education of the professionals who will spend their careers working in this new world.

What are some of those changes that need to be considered and how might we organize our thinking about the directions that those changes will take? There are a number of ways to look at reshaping educational programs but it seems that, at bare minimum, we need to consider each of the major components in any type of educational program - the students, the faculty, the curriculum and the modes of delivery - and deliberate the changes that need to be considered in each of those four components. What are the necessary changes we need to make to ensure that our schools are ready to educate the information professionals who will be vital in tomorrow's world? For each of these components, a few illustrative questions follow to set the stage for discussion:

- Students: What are the characteristics of successful information professionals? Beyond obvious characteristics such as intelligence, creativity and desire to serve others, should we recruit young people who have high tolerance for ambiguity? Analytical problem solving talent? Intuitive or empathetic interaction styles? Outgoing personalities?

- Faculty: What kinds of faculty should we recruit and promote? Generalists or specialists? Quants or quals? Exclusively from information programs or from many fields? What are the best balances 
between research and teaching? How do we evaluate research success and impact? How do we assess teaching effectiveness?

- Curriculum: Should we identify core ideas and techniques that must be included in every student's program or individualize curricula to learners? How can we balance information theories with information best practices? How comprehensive should a curriculum be? How do we evaluate student learning outcomes and career impact?

- Delivery: What is the right balance of individualized and group learning? What is the right balance of face-to-face and online learning? How can we balance coursework and in situ learning? Should information professionals be licensed?

Redesigning education for information professionals will demand an enormous effort on the part of all of us as we rethink the prior educational preparation of entering students and the role and type of faculty needed, curricular needs, and the type of pedagogy and delivery of these new programs.

Answering these and similar questions will require educational leaders to carefully assess what is essential to preserve from today's programs and what to delete, adapt and add. Most of us would say that our responsibility to the information professions of tomorrow requires us to continue to offer learning experiences that foster creative and adaptive thinking, cooperative problem solving, compassion and mutual respect, and devotion to learning and knowledge stewardship. In fact, we believe that there is a set of core values that provide the warrant for today's i-Schools and will continue to warrant our programs far into the future. There are values we share with all educational programs such as excellence, creativity, curiosity and passion for learning, but i-Schools draw their defining values from librarianship:

- Organization of information.

- Universal access.

- Collaboration.

- Intellectual freedom.

- Self-directed learning.

- Stewardship.

These values are what have distinguished our profession and have provided the basis for the service information professionals have performed for society. However, we must realize that some of these values may come into conflict with the for-profit nature of many of the organizations where our graduates will find positions. Are these values so critical to our professional identity that we will continue to insist that they remain a part of the professional preparation of every graduate?

It is these values that distinguish us from other disciplines and beginning with these values provides another basis upon which to investigate and build educational programs. Many information educators say that our schools consider the interactions of people, information, and technology. We suggest that central to this triad is the entire information life cycle and the ways that people and technology participate in this cycle. Our core values dictate the learning and teaching actions people apply to their information lives. Traditional librarianship focused most heavily on stewardship of extant information and today's information programs have broadened this mandate to the full information life cycle that includes generation, management, transmission, use/reuse and preservation:

- Information professionals are partners in generating and collecting information; they are part of the research, data mining or design team. Placing value on accurately-represented and well-organized information serves information production teams well. 
- Information professionals elicit, ingest, organize and evaluate information. They do so using distributed databases and by directing data streams. Because they value universal access, they create powerful and adaptable indexes, ontologies, and because they value stewardship, they worry about cost-effective but sustainable data structures.

- Information professionals share information openly and freely. Because they value universal access and self-directed learning, they advocate open access publishing and easy-to-use access systems.

- Information professionals are participants in using and reusing information to solve problems, make decisions, learn and play. Educating the public to find and use information, assess its accuracy and provenance, and joining small or massive teams to aggregate, synthesize, annotate or summarize are all roles that information professionals play. Because they value collaboration and learning, they are willing to go beyond simply delivering information to helping people apply it.

- Information professionals have long served as stewards of knowledge and this is even more important today for the diverse forms and volumes of digital information. Valuing access and stewardship, they know they go hand in hand and that substantial context must be included if information is to be useful in the future.

These examples of how values and the work of information professionals interact are not exhaustive but meant to suggest a basis for creating educational programs that are rooted in core values. Clearly, at each stage in the information life cycle, there are policies, costs, and systems that are essential to good theory and practice. The values we bring to the problem determine what policies and systems we develop and apply and what costs and constraints we are willing to bear.

Information Professionals 2050 provides a venue for examining these questions and thinking about how to restructure professional education to meet the needs of tomorrow. We look forward to the discussions of the next two days and hope that our activities will result in at least the beginning of a re-envisioning of the education of the next generation of information professionals. It is unlikely we will come up with a definitive plan, but we anticipate we will leave with at least an outline of where we need to go and what the next steps should be. But it will not be an easy task. Because of the disruptive changes in the information environment our past cannot serve as an adequate guide to the future. Most of us are deeply involved in education for today's information professionals and bound to some extent by our past experiences, and thus it will be hard for us to envision a vastly different education for tomorrow's professionals. If we are to be successful, we will need to set aside the model of education for information professionals with which we are all familiar and focus on the demands of the future. What will be the needs of information users in 2050 and what kind of professionals will be needed to address those needs? What are the changes that must be made in all of the components of the learning process to educate these information professionals? And finally, how do we define and preserve the core values that are essential to the information profession? We expect the discussions over the next two days will begin to provide us with some of the answers to these questions.

\section{References}

[1] P.S. Benner, Educating Nurses: A Call for Radical Transformation, Jossey-Bass, San Francisco, CA, 2009.

[2] R. Chopra, Too big to fail: student debt hits a trillion, Consumer Financial Protection Bureau, Blog posting March 21, 2012, available at: http://www.consumerfinance.gov/blog/too-big-to-fail-student-debt-hits-a-trillion/.

[3] R. Conant, The Conant Report: A Study of the Education of Librarians, MIT Press, Cambridge, MA, 1980.

[4] M.I. Cooke, Educating Physicians: A Call for Reform of Medical School and Residency, Jossey-Bass, San Francisco, CA, 2010. 
[5] C.D. Foster, Educating Clergy: Teaching Practices and Pastoral Imagination, Jossey-Bass, San Francisco, CA, 2005.

[6] J.M. Griffiths, The King Report (New Directions in Library and Information Science Education), Knowledge Industry Publications, White Plains, NY, 1986.

[7] KALIPER Advisory Committee, Educating Library and Information Science Professionals for a New Century: The KALIPER Report, Association for Library and Information Science Education (ALISE), Reston, VA, 2000.

[8] S.M. Sheppard, Educating Engineers: Designing for the Future of the Field, Jossey-Bass, San Francisco, CA, 2008.

[9] W.C. Sullivan, Educating Lawyers: Preparation for the Profession of Law, Jossey-Bass, San Francisco, CA, 2007.

[10] R. Taylor, Reminiscing about the future: professional education and the information environment, Library J. 104 (1979), $1871-1875$

[11] J. Wheeler, Progress and Problems in Education for Librarianship, Carnegie Corporation, New York, NY, 1946.

[12] C. Williamson, The Williamson Reports of 1921 and 1923, Scarecrow Press, Metuchen, NJ, 1971. 